\title{
Igniting Collective Freedom: An Integrative Behavioral Model of Acceptance and Commitment towards Black Liberation
}

\author{
Denisha Gingles
}

Signature Behavior Analytic Services, LLC, Baltimore, MD, USA

Author Note: Denisha Gingles(she/her) is a Black American/descendant of enslaved ancestors and a cisgender woman. It is through the lens of collective and cultural healing this manuscript was prepared. This manuscript uplifts Black researchers who have paved the way for this discourse and encourages room for expansion beyond colonialism and anti-Black racism. 


\begin{abstract}
Racism continues to reveal disastrous effects for the Black community. There exists no behavior analytic literature with a specific focus on ending Black psychological suffering due to continual acts of violence perpetrated against the community. The author presents a behavioral model to promote Black psychological liberation, infusing pre-established frameworks of Black Psychology and cultural healing practices with acceptance and commitment therapy. The model addresses behaviors observed within systemic and internalized racism.
\end{abstract}

Keywords: Black Liberation, Acceptance and Commitment Therapy, Relational Frame Theory, Racial Trauma, Internalized Racism, Anti-Blackness 
This manuscript is being published on an expedited basis, as part of a series of emergency publications designed to help practitioners of applied behavior analysis take immediate action to address police brutality and systemic racism. The journal would like to especially thank Robin Williams and Taira Bermudez for their insightful and expeditious reviews of this manuscript. The views and strategies suggested by the articles in this series do not represent the positions of the Association for Behavior Analysis, International or Springer Nature.

Editor, Jonathan Tarbox 


\section{Igniting Collective Freedom: An Integrative Behavioral Model of Acceptance and Commitment for Black Liberation}

"We want our bodies back. We want them returned to mothers; without blood, without brains exposed. Without humiliation, without bruises, without glass, without fire. We want our bodies back. We want our cities back. We want our culture back. We want our land back. We want our streets back. We want our freedom. We want our justice.”

Poet, Jessica Care Moore

Black Psychology is defined as the study of Black behavioral patterns (Smith, 1974). The study of Black behavioral patterns dates back to the work of Francis C. Sumner, also regarded as the father of Black Psychology. The blueprint continued with pioneers like Inez Prosser, Herman Canady, Mamie Clark, Kenneth Clark, Martin B. Jenkins, Alberta Banner Turner, and Maxie Clarence Maultsby Jr., who were vital in promoting Black psychology and moving away from the standard western European model of pathology and exploitation unfairly bestowed upon them by white leaders who perpetuated racism in academic and clinical spaces (APA, 2012; APA, 2019; Jamison, 2018). To date, Black psychologists have created theories and frameworks tailored to the Black community using relative and culturally specific teachings that improve their own lives (Clark et al., 1975; Chimezie, 1975; Baldwin, 1979; Turner and Jones, 1982).

There existed, and continues to exist, a need for the Black community to have contextually relevant frameworks and interventions directly from professionals who are similar to them (Chimezie, 1975; Delgado and Stefanic, 2001; Abrams et al., 2020; Awad et al., 2020; Cabral and Smith, 2011). In particular, Black Americans have a unique shared learning history that extends to this country's founding. The long-running history of violence, genocide, eugenics, and other oppressive practices that the Black community endured, and in some areas 
continue to endure, will require an approach that seeks to remediate the damage, both tangible and psychological. Critical race theory (Delgado and Stefanic, 2012) tells us that taking a colorblind approach to human behavior reveals a failure to include an individual's learning history and personal cultural context that may impact their world view and actions. While the damage from racism can never be repaired, there needs to exist a model for Black liberation that can be objectively measured and defined for the individual and the community. I aim to offer a framework and suggestions for quantifying and targeting behaviors to encourage Black psychological liberation in the service of actualizing freedom.

\section{Defining the Problem}

While this paper will outline a model of liberation, it is essential to frame the environmental contingencies that exist as a threat for the Black community to both achieve emancipation that would include freedom from incarceration, equitable housing, education, wealth, and healthcare and engage in discrete behaviors that would help to produce such an impact. The biggest threat to Black liberation is structural racism; in fact, it can be considered the antithesis of it. The etiology of structural racism in America begins in the $15^{\text {th }}$ century and expands in the $17^{\text {th }}$ century with the first documented heinous acts inflicted upon Indigenous and Black persons to include, but are not limited to, colonization, indoctrination, rape, and murder (Smithsonianmag.com, 2020). Structural racism refers to the norming of hegemonic whiteness and hierarchical classifications as part of a relational network that benefits those who are phenotypically white and/or white identifying. Structural racism describes the embodiment of inequitable practices within institutions or systems and includes policies that disproportionately impact individuals who fall outside of the social categorization of whiteness (Lawrence, 2004). 
It would be non-behavior analytic to fail to include that while a system of oppression (hereafter referred to as the system) exists, it does not run or exist without the permission and action of living individuals. The system was created through language and defined by a verbal community that shaped and reinforced concrete discriminatory practices and behaviors. Therefore it is the verbal community that maintains systemic oppression and remains each individual's responsibility to assess their own behaviors that help to keep the system working as designed.

Also necessary to frame is anti-Black racism. Anti-Black racism captures structural, systemic, and individual racism; however, it directly targets individuals who are socially categorized as Black. The impact of structural racism and anti-Blackness is well researched (Utsey, 1999; Greer, 2011; Helms, 2006; Maxwell, 2014; Jones, 2013). Examples of the impacts of racism and/or race-related stress include health disparities and injustices, environmental racism, higher incarceration rates, higher homeless negative emotional responses, internalized racism or self-stigma, anxiety, depression, and lower life satisfaction (Jones, 2007; Utsey, 2008; Graham et al., 2014). Racism is clearly a socially significant issue for all of us, including behavior analysts.

\section{Defining Black Liberation}

"The idea of freedom is inspiring. But what does it mean? If you are free in a political sense but have no food, what's that? The freedom to starve?"

Activist, Angela Davis

The section title evokes the question, “can Black liberation be defined?" The short answer is yes. Black liberation, as a defined practice, has roots in both psychology and theology. According to Black Liberation Theology founder, James Hal Cone, Black liberation is "the 
affirmation of Black humanity that emancipates Black people from racism and confronts issues that are part of the reality of Black oppression (Lincoln, 1974 as cited by Azibo, 1994). Black Liberation Psychology, to Azibo, proposes a new way of living free from white supremacy by honoring African and indigenous cultural practices (1994).

Liberation also has roots in the behavior analytic literature and has previously been defined. Skinner discussed freedom, in relation to government, as the absence from aversive controls (1953). He regarded the temporal nature of aversive consequences as either immediate or deferred. This means a person may experience aversive stimuli in their current environment or may experience it in their environment at a later time. Goldiamond expanded this work, referring to freedom in context to the availability of choice. The availability and number of genuine choices constitute the degree of freedom the individual actually holds. In his work, the greater the degree of freedom, the lower the degree of coercion or aversive consequences present (1976, pg. 36). Though Black people are technically free in our Global society, we must consider to what degree this is true.

For this paper, I consider Black liberation as a concept, value, and an outcome that can be actualized for the group and individual. The Combahee River Collective, a Black feminist organization, named after Harriet Tubman's raid that freed 750 enslaved people, imagined liberation as the destruction of the political-economic systems of capitalism, imperialism, and patriarchy (2017). Baum referred to freedom as the reduction of imprisonment and enslavement (2017). As a concept, Black liberation may initially seem abstract and non-behavioral; however, it can be conceptualized behaviorally as both a tact and a mand. Black liberation as a concept is helpful to describe behaviors that are important to the group. For instance, tacting or defining Black liberation may be the freedom to go for a run without being murdered (and also a mand). 
For this to be true, others, and in this specific example, white people must provide consequences that reinforce freedom in this context.

Black liberation as a value is similar to the concept; however, it can further verify the individual's connection to the term. Values are defined as "rules that function as verbal motivating operations that increase or decrease the effectiveness of stimuli as reinforcers or punishers, thereby supporting overt behaviors that produce those stimuli” (Tarbox et al., 2020). If someone has self-identified Black liberation as a value, it would likely promote behaviors in the service of freedom of oneself and/or community. Behavior in the service of freedom of one's self is regarded as self-liberation. It involves reclaiming autonomy and rejecting oppressive systems that, to some degree, have controlled their behaviors in the past. As a value, selfliberation may entail an individual intentionally setting conditions to evoke their own behavior that, as a result of rule-governed behavior and aversive contingencies, may have previously been punished (Duttry, 2014). For example, calling out racism in real-time, dressing and speaking in ways that are authentic to one's culture, and self-advocacy, despite being met with an aversive consequence from others. Black liberation in service of the freedom of one's community is referred to as collective liberation. Collective liberation includes efforts that positively enhance the shared experience of the group. For example, a person who values collective Black liberation may be more likely to support Black-led community organizations and voices financially or through volunteerism (Ramone, 2014).

As an outcome, Black liberation speaks to dismantling all barriers that specifically and disproportionately impact the community. Though the enslavement and forced labor of Black people technically ended in 1865, the results are still residual (Degruy Leary, 2005; Wilkens et al., 2012), and the tenets of racism and oppression are still present in today's society. Michelle 
Alexander discussed the function of new laws and practices, such as mass incarceration, as equivalent to the function of slavery (2010). Other residual effects include residential segregation, workforce discrimination such as steering Black people into limited mobility career positions, and electoral oppression such as voter suppression and racial gerrymandering (BonillaSilva, 2017). All the aforementioned examples reinforce the maintenance of white supremacy and privilege and, in turn, further oppress Black people, similarly to chattel slavery. Some critical outcomes of Black liberation efforts include Black Americans receiving reparations, closing the wealth gap, closing the healthcare gap, and ending mass incarceration.

Black liberation regarded as a concept, value, and outcome are intentional in this text and should remain interconnected. Should Black liberation be considered a concept alone, one may fail to engage in the values-directed actions of advocating for and demanding external change in organizations at local, state, and federal levels. I argue that Black liberation is both attainable and accessible. I further contend that behavior analysts can attend to and behave in favor of Black liberation. Behavior analysts have an ethical obligation to address socially significant problems (Wolf, 1978), and therefore we have an ethical obligation to address our American legacy of 400 years of oppression.

\section{Role of Black Behavior Analysts in Black Liberation}

In 1989, Joseph Baldwin called for Black Psychologists to concede their role in maintaining oppressive systems and take up their place as co-conspirators for Black liberation. His essay later served as marching orders for other Black professionals to develop culturally relevant interventions for the community's advancement. Black Behavior Analysts: we also have a duty to our community to ensure we are not complicit in systemic oppression. Whether we are Black academics, Black clinicians, Black researchers, or Black professors, we must ensure we 
are vocal and working towards a collective solution of Black freedom. The Black community's needs cannot be better tacted by anyone else other than members of the Black community. It is a necessary burden that we remain on the frontlines of defining and ensuring our emancipation. While it is not a burden that is ours to bear alone, we must be steadfast in crafting solutions that embody the needs and the cultural contingencies unique to our people. In addition to other racial groups, we will need to engage in the work necessary to consider how we have personally been impacted by racism and how racism reveals itself in the way we work and show up in the world. We will need to address the desire to rely on white European ideals and standards to "save" our community and ourselves. We will also need to confront how we choose models for our behavior. This work will not be without its challenges, so it will be necessary to offer a personal commitment to Black liberation. While we stand firmly against racism, we must stand firmly for liberation.

\section{Internalized Racism and Anti-Blackness}

Internalized racism is defined as the resignation of "attitudes, beliefs, ideologies, and stereotypes created by the dominant white society as being true about one's racial group" (Molina \& James, 2016). Internalized racism is not separate from structural racism; it is part of it and a byproduct of it. Examples of internalized racism and anti-Blackness may include, but are not limited to, beliefs that Black people are inferior to other racial groups, are naturally less attractive, less intelligent, or more violent. It may also include non-Black people as inherently delicate, smart, beautiful, well-spoken, positive, and upbeat. Internalized racism may even sound like an individual saying Black people should dress a certain way to be deemed respectable to other people. In this regard, it maintains that other racial group characteristics are the norm and Blackness, and its many presentations, are not. The belief of Blackness only existing in 
comparison to another racial group or culture, more specifically whiteness, may also speak to the internalization of racism. This is taught through verbal behavior, that the individual is not free to define themselves on their own and must rate and organize their behavior to emulate that of others. Existing as a comparative marker to other groups denies the uniqueness and autonomy of the Black community.

Internalized racism can be conceptualized using multiple behavior analytic processes. For example, rule-governed behavior applies to this concept, even when the rules related to whiteness as normative are arbitrary and false (e.g., "If a person is light or fair-skinned, they are good looking"). It also can be understood using relational frame theory (RFT; Figure1; Dixon et al., 2003). Racism is equivalent to a social caste system, which is embedded in hierarchical framing. Internalized oppression then speaks to learning comparative frames regarding others and oneself (white people are better looking than Black people). Given the behavioral literature on derived relational networks, Black people will not merely "unlearn" what we were taught about ourselves, one another, and our cultural behaviors in relation to other races. Figure 2 depicts a relational network including African American Vernacular English (AAVE) that is likely common among Black Americans. Relational networks, however, can be expanded, which may evoke variability in responding, but previous learning will not be erased. Therefore, Black liberation is not about getting rid of relational frames but more about changing our relationship to the content by adding to our networks and shifting behavioral patterns as a result.

Additionally, a four-term contingency model can be useful for behaviorally analyzing internalized racism and anti-Black behaviors. Figures 3-5 depict four-term contingencies, including conditional discriminations, which bring specific contingencies under contextual control (Cooper et al., 2019). In each, one may view a conditional sample as skin color (i.e., 
being in the presence of a white or Black person). In Figure 3, in the presence of a white person, the Black speaker selects an incorrect response (i.e., speaking in AAVE), resulting in punishment or error-correction. In Figure 4, in the presence of a white person, the Black speaker selects the “correct response" (i.e., speaks in English standard language) and receives reinforcement. In Figure 5, in the presence of a Black person, the Black speaker speaks in AAVE and contacts reinforcement. In each of these examples, the conditional sample (i.e., the skin color of the person present) then serves as a reflexive conditioned motivating operation for the Black speaker in the future. In addition, each of these examples serves as a context for the Black speaker to derive a rule about how they "should" or "shouldn't" talk, based on who is present.

It is important to note that these behaviors can be evoked without direct training. Through verbal behavior processes of arbitrarily applicable derived relational responding (such as being told about the contingencies outlined in the previous example), an individual's behavior may fall under the same control. Should an individual experience this contingency directly, it will likely strengthen (or create) the rule of shifting linguistic behavioral patterns in the presence of certain stimuli. Therefore understanding rule-generation and other complex verbal processes can be helpful in understanding overt behaviors as an outcome of internalized racism.

Once an individual has acquired relational networks that include frames of reference to their own identity, they may, in turn, enact the same or similar behaviors of those as the dominant group against others in their own racial group as a response to an established "rule." This may lead to delivering consequences or enacting behaviors that may be aversive to their own group and simultaneously reinforce structural and systemic racism. Black people who are victims of racism can also become perpetrators of it through this process. To much dismay, a person who exhibits behaviors representative of those who fall outside of their racial category 
may experience a more positive sense of self, as engaging in these behaviors creates a context for the individual to relate themselves as "different than" (i.e., relational framing in terms of distinction) other members in their racial classification. Members of the group who display behaviors in alignment with their own oppression may also receive positive reinforcement from those of dominant identity groups (or other racial minority groups) in the form of social praise or other conditioned reinforcers. For example, a Black person who verbally chastises other Black people in a public, predominately white forum may be praised as being "one of the good ones." With the signaling of reinforcement for Black individuals who perpetuate anti-Blackness, this may be a strong competing reinforcer for Black liberation. While it serves as momentary reinforcement, and to the individual could potentially be tacted as self-liberation, it hinders progress on behalf of the collective and impacts the individual's psychological liberation.

Lastly, as a necessary reminder, achieving freedom does not solely rest on the oppressed. While this model includes a collaborative effort for Black people to advance collective and individual freedom, the responsibility of ensuring freedom still rests on a collective of white individuals with social and political power, who created the system of means for advantage and cultural preservation. Even if found to be of utility to the Black community, a psychological model could never replace the necessity to dismantle structural racism, i.e., the outcomes of Black liberation and white supremacy. Non-Black People of Color also have a responsibility to dismantle anti-Black oppression (Li, 2020). Though this topic is beyond this paper's scope, behavior analysts may pull from previous behavior analytic literature as a model of recognizing power dynamics (Maittaini, 2017). 


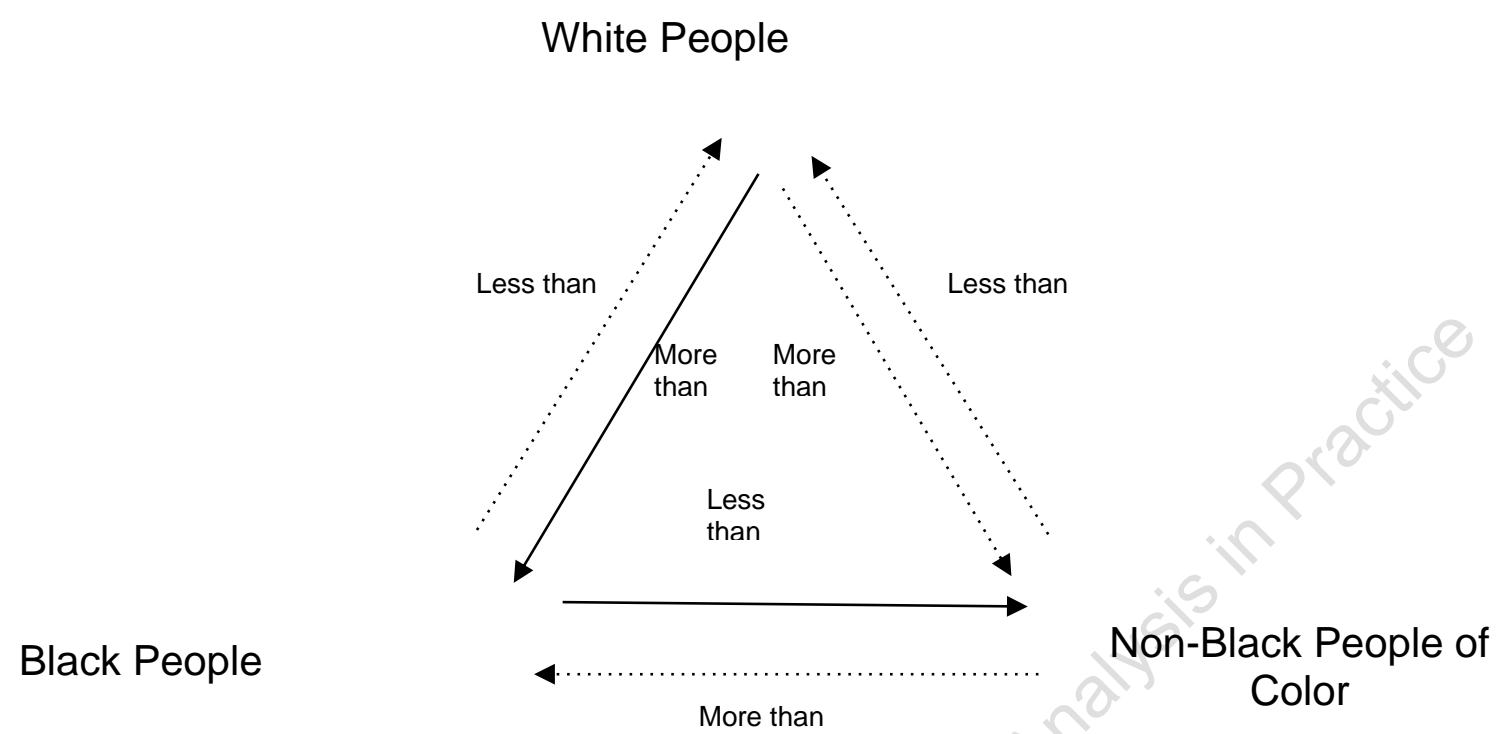

Figure 1. Behavioral sample of internalized racism using comparative relational framing. An individual may have been taught white people are more (any adjective can be filled in) than Black and other people of color. Also, non-Black people are more (adjective) than Black people. With this teaching, one derives that Black people are less (adjective) than both Non-Black and white people. The solid lines in this figure represent relations that have been directly trained, while the dotted lines represent derived relations (not directly trained). 


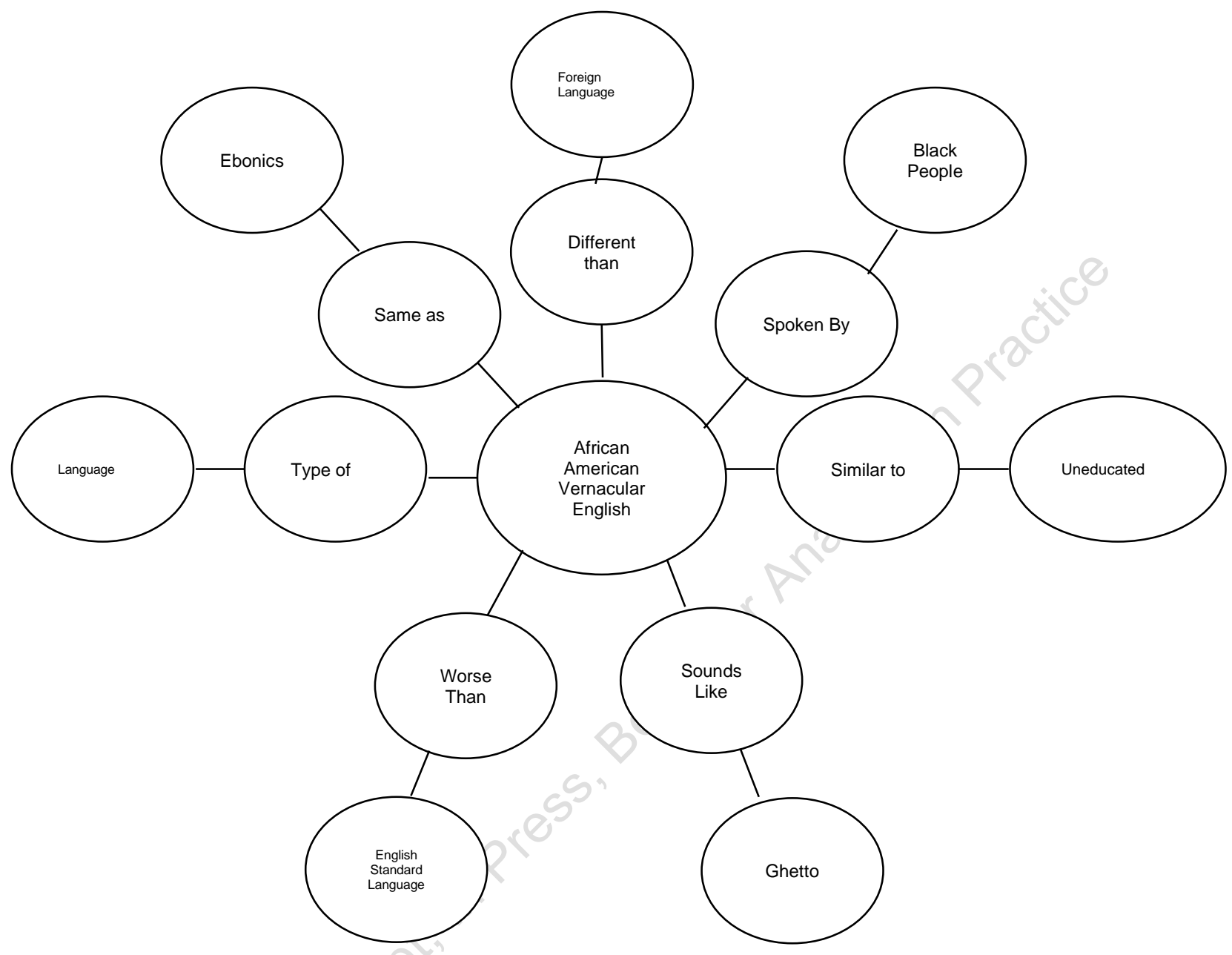

Figure. 2 Example of a network of relational framing behavior surrounding African American Vernacular English (AAVE).
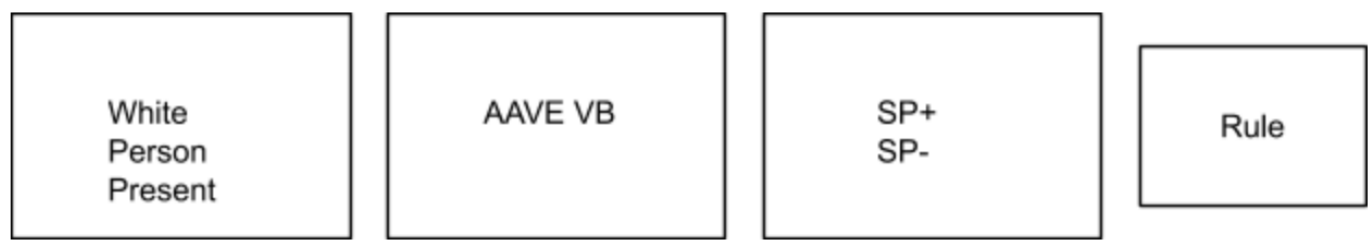
Figure 3. Example of a potential four-term contingency wherein the individual experiences direct aversive consequences for speaking in AAVE. The likelihood of using this modality of speaking in the future decreases, and the individual may derive a new rule.

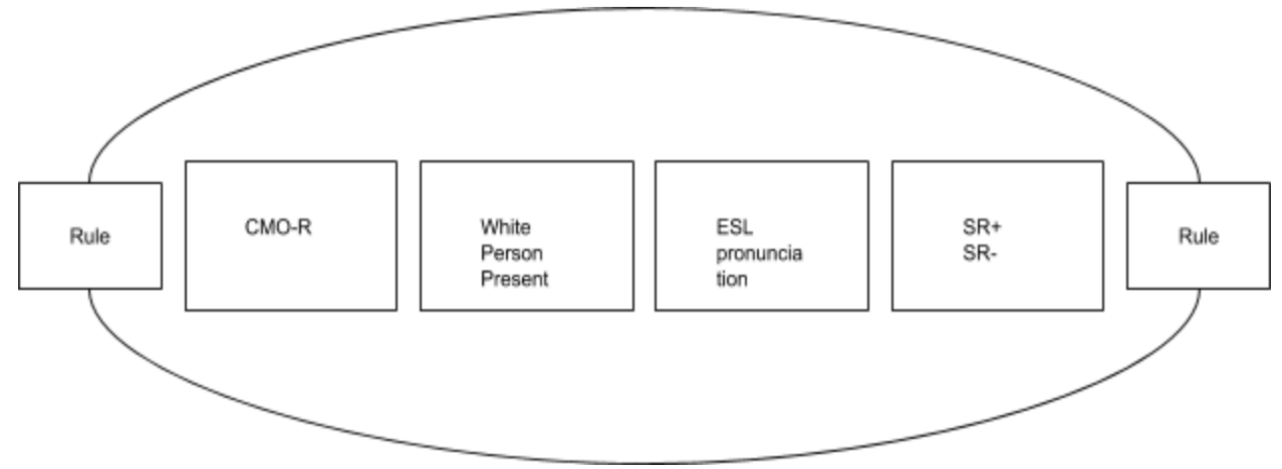

Fig 4. This graphic incorporates rule-deriving that may be assessed as part of the standard contingency model. Rule governance involves verbal antecedents and behavior that is not directly trained. Additionally, rule governance can be strengthened, following the consequences of certain behaviors. In this case, the rule that one must speak in English standard language when white people are present, followed by positive or negative reinforcement, an individual may emit confirmatory verbal behavior of the rule in the future, as well as deriving additional new racerelated rules.

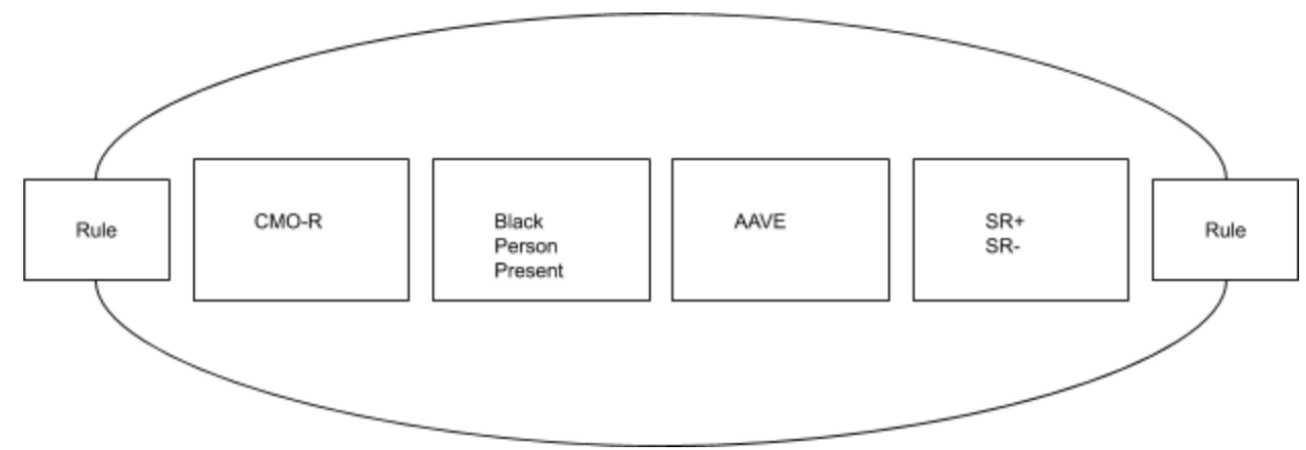


Fig 5. Example of a four-term contingency surrounding the behavior of speaking in AAVE around Black individuals. Similar to the functional relations depicted in Figure 4, this four-term contingency establishes race-related behavior, as well as serving as a context to derive rules surrounding such behavior.

\section{Behavior Analytic Considerations for Internalized Racism and Anti-Black Behaviors}

Similarly to working with any individual, behaviors to consider would be based upon and chosen by that person. Self-selection of behaviors and autonomy are vital components to consider when addressing individuals with a history of aversive socially mediated consequences. Self-selection refers to the presence of motivating operations that produces an evocative effect for the selection of certain behavior. Behavior analysts may also pull from the literature on selfmanagement to assist individuals who have self-selected behaviors for change(Cooper et al., 2019). Self-management is "the personal application of behavior change tactics that produce a desired improvement in behavior"(Cooper et al., 2019). Black individuals may monitor their own behavior in relation to internalized racism, both public and private, and take action to change the manipulable stimuli in their environment so their behavior changes in value-consistent methods. An example may be an individual who self-monitors a shift of linguistic behaviors in the presence of non-Black individuals, may provide a prompt and re-shift back to their natural tongue.

An individual who has internalized racism or displays anti-Black behaviors (which is likely every person that has been part of a racist environment at some point of their learning history) may first need to label rules or objectively define behaviors they engage in that have been taught and reinforced by non-Black people (and potentially other Black people). This will require flexibility and honesty. Approaching internalized racism is likely to prove challenging as 
a person may display what psychologists call cognitive dissonance, which refers to changing an evaluation in a direction and congruent with a pre-existing frame of reference (Osgood and Tannebaum, 1955; Festinger, 1957). Therefore internalized racism or anti-Black behaviors may not be easily tacted or denied even when presented with new evidence. Behavior analysts may assist by working to define examples of internalized racism and anti-Black actions (Figure 6).

Internalized Racism and Rule Governed Behavior Scale

\begin{tabular}{|c|c|c|c|}
\hline Statement & Example & Scoring Criteria & Score \\
\hline $\begin{array}{l}\text { I believe some } \\
\text { stereotypes about } \\
\text { Black people are true }\end{array}$ & Black people are loud & $\begin{array}{l}\text { 0- I do not believe this } \\
\text { 1-Sometimes I believe } \\
\text { this } \\
\text { 2-Generally I believe } \\
\text { this }\end{array}$ & 5 \\
\hline $\begin{array}{l}\text { If Black people are } \\
\text { well dressed and } \\
\text { groomed, they have a } \\
\text { better chance to gain } \\
\text { the respect of other } \\
\text { races }\end{array}$ & $\begin{array}{l}\text { Black people should } \\
\text { pull up their pants } \\
\text { and not expose their } \\
\text { private parts }\end{array}$ & $\begin{array}{l}0-\text { I do not believe this } \\
1 \text {-Sometimes I believe } \\
\text { this } \\
\text { 2-Generally I believe } \\
\text { this }\end{array}$ & \\
\hline $\begin{array}{l}\text { I am suspicious of a } \\
\text { large group of Black } \\
\text { people in certain } \\
\text { areas }\end{array}$ & $\begin{array}{l}\text { If I see a large group } \\
\text { of Black people while } \\
\text { in an inner-city, I } \\
\text { move away }\end{array}$ & $\begin{array}{l}0 \text { - I do not believe this } \\
\text { 1-Sometimes I believe } \\
\text { this } \\
\text { 2-Generally I believe } \\
\text { this }\end{array}$ & \\
\hline $\begin{array}{l}\text { I emit protective } \\
\text { behaviors when I see } \\
\text { a group of Black } \\
\text { people approaching, } \\
\text { depending on where I } \\
\text { am at }\end{array}$ & $\begin{array}{l}\text { I start walking slower } \\
\text { or faster to my } \\
\text { car/destination }\end{array}$ & $\begin{array}{l}\text { 0- I do not do this } \\
\text { 1-Sometimes I do this } \\
\text { 2-Generally I do this }\end{array}$ & \\
\hline $\begin{array}{l}\text { I generally ascribe } \\
\text { attractiveness to Light } \\
\text { skin Black people }\end{array}$ & $\begin{array}{l}\text { If I see a group of } \\
\text { multi-toned Black } \\
\text { women, I visually } \\
\text { attend to the lighter- } \\
\text { skinned woman }\end{array}$ & $\begin{array}{l}0 \text { - I do not do this } \\
\text { 1-Sometimes I do this } \\
\text { 2-Generally I do this }\end{array}$ & \\
\hline $\begin{array}{l}\text { At work, the approval } \\
\text { of my work from }\end{array}$ & $\begin{array}{l}\text { I look for feedback } \\
\text { from white }\end{array}$ & $\begin{array}{l}0 \text { - I do not believe this } \\
\text { 1-Sometimes I believe }\end{array}$ & \\
\hline
\end{tabular}




\begin{tabular}{|c|c|c|c|}
\hline $\begin{array}{l}\text { white colleagues and } \\
\text { supervisors is } \\
\text { important }\end{array}$ & $\begin{array}{l}\text { peers/colleagues to } \\
\text { indicate I am doing a } \\
\text { good job }\end{array}$ & $\begin{array}{l}\text { this } \\
\text { 2-Generally I believe } \\
\text { this }\end{array}$ & \\
\hline $\begin{array}{l}\text { I struggle to trust } \\
\text { Black people in } \\
\text { leadership positions }\end{array}$ & $\begin{array}{l}\text { I think Black people } \\
\text { in leadership } \\
\text { positions have a } \\
\text { hidden agenda }\end{array}$ & $\begin{array}{l}0 \text { - I do not believe this } \\
\text { 1-Sometimes I believe } \\
\text { this } \\
\text { 2-Generally I believe } \\
\text { this }\end{array}$ & \\
\hline $\begin{array}{l}\text { In public, I feel } \\
\text { ashamed when Black } \\
\text { people talk loud or } \\
\text { yell }\end{array}$ & $\begin{array}{l}\text { I look at other non- } \\
\text { Black people to } \\
\text { observe their } \\
\text { reactions and shake } \\
\text { my head to show } \\
\text { disagreement with the } \\
\text { actions of the loud } \\
\text { Black people }\end{array}$ & $\begin{array}{l}0 \text { - I do not believe this } \\
\text { 1-Sometimes I believe } \\
\text { this } \\
\text { 2-Generally I believe } \\
\text { this }\end{array}$ & 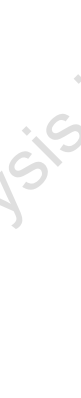 \\
\hline $\begin{array}{l}\text { When choosing a } \\
\text { professional service } \\
\text { provider, I am more } \\
\text { likely to select } \\
\text { someone who is non- } \\
\text { Black }\end{array}$ & $\begin{array}{l}\text { I will hire a non- } \\
\text { Black accountant } \\
\text { even when I have } \\
\text { revealed Black } \\
\text { accountant with equal } \\
\text { skills and abilities }\end{array}$ & $\begin{array}{l}0 \text { - I do not do this } \\
\text { 1-Sometimes I do this } \\
\text { 2-Generally I do this }\end{array}$ & \\
\hline $\begin{array}{l}\text { I prefer to live in a } \\
\text { mixed neighborhood } \\
\text { or non-Black } \\
\text { neighborhood }\end{array}$ & $\begin{array}{l}\text { When looking for a } \\
\text { new home, I will } \\
\text { choose a mixed or } \\
\text { non-Black } \\
\text { neighborhood instead } \\
\text { of one that is } \\
\text { predominantly Black }\end{array}$ & $\begin{array}{l}0 \text { - I do not believe this } \\
\text { 1-Sometimes I believe } \\
\text { this } \\
\text { 2-Generally I believe } \\
\text { this }\end{array}$ & \\
\hline $\begin{array}{l}\text { Natural hair is not } \\
\text { professional or } \\
\text { upscale }\end{array}$ & $\begin{array}{l}\text { Black people should } \\
\text { wear their hair } \\
\text { straight }\end{array}$ & $\begin{array}{l}0 \text { - I do not believe this } \\
\text { 1-Sometimes I believe } \\
\text { this } \\
\text { 2-Generally I believe } \\
\text { this }\end{array}$ & \\
\hline $\begin{array}{l}\text { Black people must } \\
\text { code-switch to get } \\
\text { ahead in life }\end{array}$ & $\begin{array}{l}\text { Black people must } \\
\text { use English Standard } \\
\text { Language to succeed }\end{array}$ & $\begin{array}{l}0 \text { - I do not believe this } \\
\text { 1-Sometimes I believe } \\
\text { this } \\
\text { 2-Generally I believe } \\
\text { this }\end{array}$ & \\
\hline Black people need to & Black people need to & 0- I do not believe this & \\
\hline
\end{tabular}




\begin{tabular}{|c|c|c|c|}
\hline $\begin{array}{l}\text { fix their own issues } \\
\text { before demanding it } \\
\text { of other races }\end{array}$ & $\begin{array}{l}\text { regulate gun violence } \\
\text { before demanding the } \\
\text { end of police violence }\end{array}$ & $\begin{array}{l}\text { 1-Sometimes I believe } \\
\text { this } \\
\text { 2-Generally I believe } \\
\text { this }\end{array}$ & \\
\hline $\begin{array}{l}\text { Black people are their } \\
\text { worst enemy. }\end{array}$ & $\begin{array}{l}\text { Black people are the } \\
\text { reason for their } \\
\text { demise }\end{array}$ & $\begin{array}{l}0 \text { - I do not believe this } \\
\text { 1-Sometimes I believe } \\
\text { this } \\
\text { 2-Generally I believe } \\
\text { this }\end{array}$ & \\
\hline $\begin{array}{l}\text { Black people are less } \\
\text { professional than } \\
\text { other races }\end{array}$ & $\begin{array}{l}\text { Black people are late, } \\
\text { rude, and do not } \\
\text { render adequate } \\
\text { services }\end{array}$ & $\begin{array}{l}0 \text { - I do not believe this } \\
\text { 1-Sometimes I believe } \\
\text { this } \\
\text { 2-Generally I believe } \\
\text { this }\end{array}$ & $\cdot 5$ \\
\hline $\begin{array}{l}\text { Black people are like } \\
\text { crabs in a barrel }\end{array}$ & $\begin{array}{l}\text { Black people do not } \\
\text { want to see one } \\
\text { another succeed and } \\
\text { will sabotage } \\
\text { someone who is } \\
\text { excelling }\end{array}$ & $\begin{array}{l}0 \text { - I do not believe this } \\
\text { 1-Sometimes I believe } \\
\text { this } \\
\text { 2-Generally I believe } \\
\text { this }\end{array}$ & \\
\hline $\begin{array}{l}\text { Black people who } \\
\text { cannot/do not } \\
\text { codeswitch are ghetto } \\
\text { or uneducated }\end{array}$ & $\begin{array}{l}\text { When Black people } \\
\text { speak with incorrect } \\
\text { English Standard } \\
\text { Language use, I judge } \\
\text { their intelligence or } \\
\text { correct them }\end{array}$ & $\begin{array}{l}0 \text { - I do not believe this } \\
\text { 1-Sometimes I believe } \\
\text { this } \\
\text { 2-Generally I believe } \\
\text { this }\end{array}$ & \\
\hline $\begin{array}{l}\text { If a group of Black } \\
\text { men pass me on the } \\
\text { street, I feel nervous }\end{array}$ & $\begin{array}{l}\text { My heart rate } \\
\text { increases when a } \\
\text { group of Black men } \\
\text { are walking past me }\end{array}$ & $\begin{array}{l}0 \text { - I do not believe this } \\
\text { 1-Sometimes I believe } \\
\text { this } \\
\text { 2-Generally I believe } \\
\text { this }\end{array}$ & \\
\hline $\begin{array}{l}\text { Black women have } \\
\text { attitude problems. }\end{array}$ & $\begin{array}{l}\text { Black women } \\
\text { complain for no } \\
\text { reason }\end{array}$ & $\begin{array}{l}0 \text { - I do not believe this } \\
\text { 1-Sometimes I believe } \\
\text { this } \\
\text { 2-Generally I believe } \\
\text { this }\end{array}$ & \\
\hline $\begin{array}{l}\text { Black people are not } \\
\text { safe when they leave } \\
\text { the house. }\end{array}$ & $\begin{array}{l}\text { Black people risk } \\
\text { being assaulted, } \\
\text { jailed, or murdered } \\
\text { when they leave their }\end{array}$ & $\begin{array}{l}\text { 0- I do not believe this } \\
\text { 1-Sometimes I believe } \\
\text { this } \\
\text { 2-Generally I believe }\end{array}$ & \\
\hline
\end{tabular}




\begin{tabular}{|c|c|c|c|}
\hline & home & this & \\
\hline $\begin{array}{l}\text { Black people should } \\
\text { avoid speaking about } \\
\text { topics and using } \\
\text { colloquialism that } \\
\text { reinforce Black } \\
\text { stereotypes }\end{array}$ & $\begin{array}{l}\text { Black people should } \\
\text { not speak about topics } \\
\text { that reinforce Black } \\
\text { stereotypes }\end{array}$ & $\begin{array}{l}0 \text { - I do not believe this } \\
\text { 1-Sometimes I believe } \\
\text { this } \\
\text { 2-Generally I believe } \\
\text { this }\end{array}$ & \\
\hline $\begin{array}{l}\text { Black people will } \\
\text { never receive } \\
\text { liberation. }\end{array}$ & $\begin{array}{l}\text { Black people will } \\
\text { always suffer from } \\
\text { racism }\end{array}$ & $\begin{array}{l}0 \text { - I do not believe this } \\
\text { 1-Sometimes I believe } \\
\text { this } \\
\text { 2-Generally I believe } \\
\text { this }\end{array}$ & .5 \\
\hline
\end{tabular}

Figure 6. An example of using outlining behaviors that may reflect internalized racism and anti-

Blackness. Behavior analysts may develop behavioral scales that can help an individual determine which anti-Black behaviors to change.

\section{Collective and Racial Trauma}

Racism has been studied to cause psychological stress and trauma for Black Americans

(Pieterse et al., 2012). Trauma, as it relates to racial tension, is referred to in the literature as racial trauma. Racial trauma is defined as reactions to dangerous events related to real or perceived experiences of racial discrimination (Comas-Díaz \& Neville, 2019). Comas- Díaz and Neville further outline events such as threats of harm or injury, slavery, humiliation, and shaming, witnessing or hearing about events, systemic oppression, community, and police violence. The impact of racial trauma may be observed as anger, headaches, depression, chest pains, back pains, hypervigilance/arousal, sleep disturbance, and ulcers (Truong and Museus, 2012).

Collective trauma is defined as a shared learning history or psychological reaction to a traumatic event that affects an entire society (Hirshberger, 2018). Events included in collective trauma are genocide, mass shootings, wars, terrorism, migration, natural disaster, and slavery. 
The impact of collective trauma for individuals may include sleep disturbance, hypervigilance, isolation/withdrawal, irritability, anger, guilt, self-doubt, avoidance, negative emotions and mood, flashbacks, and excessive activity levels (APA, 2013). The impact of collective trauma also may include passing down culturally derived teachings and traditions about threats that promote group preservation, amplifying existential concerns, and increasing motivation to remember the trauma as a symbolic system of meaning (Comas-Díaz \& Neville, 2019). During periods of collective trauma, community members may feel a more profound sense of connection to other community members.

For Black people, understanding the impacts of both racial and collective trauma may serve as a useful tool to identify when responding to environmental stimuli that may be acting as racial-related stressors. Racial trauma may be present even when we may not be aware of it. Often, we do not realize daily stressors that may affect our psychological or physiological health (APA, 2013). Collective trauma may reveal itself when stories or videos emerge of statesanctioned violence initiated by police officers. Research confirms prolonged mental impact after viewing police killings of unarmed Black men, even after 1 or 2 months of the initial exposure. This is not the case for white respondents (Bor et al., 2018).

\section{An Integrative Behavioral Model for Black Psychological Liberation}

Infusing existing models of ACT, storytelling, and a functionally appropriate traumafocused lens is aimed at using tools readily at our disposal that honor the ancestral spirit of the Black community and can potentially promote Black liberatory behaviors. While a term such as "ancestral spirit" may sound unconventional to behavior analysts, it should be noted that it may hold significance to the target population (Clark, 2013). To translate, the ancestral spirit speaks 
to social and cultural validity (Solano-Flores \& Nelson-Barber, 2001). The following sections of this paper will overview modalities that may be combined to actualize Black liberation.

\section{Acceptance and Commitment Therapy}

Acceptance and Commitment Therapy is a functional contextual framework that bolsters values-driven action and fosters psychological flexibility through six core processes: acceptance, cognitive defusion, flexible attention to the present, self-transcendence, values, and committed action (Hayes, 2019; French et al., 2017). The contextualist framework promotes explicit naming of our values and the goals necessary to work towards those values, in this case, Black Liberation (Biglan and Embery, 2013). Functional contextualism, both radical and conceptually systematic, claims that measuring outcomes that improve all people's wellbeing, including being free from disease, attack from others, adequate food and shelter, is possible. This stance provides the foundation for using ACT and functional contextualism to promote Black liberation.

ACT, while popularized in modern mainstream psychology, reveals components native to Black and Brown communities prior to its founding that are often left out of contemporary discourse. The purpose of presenting this model is not to deny the longstanding solutions developed by the Black community prior to ACT's founding, but to bring attention to the parallels that may be further explored in the behavior analytic sphere. The methodology uses ancient East practices, as it embeds flexible attention to the present moment, defusion, and acceptance practices, which is traditionally referred to as mindfulness, into the model. It would be disingenuous not to mention that while acceptance and commitment therapy show promise, there is no specific evidence base that uses Acceptance and Commitment therapy to address internalized racism. While ACT has not proven to be effective yet with the Black community in this specific context, the incorporation of mindfulness speaks to its potential as Mindfulness- 
based practices have been shown efficacious (Woods-Giscombé, C. L., \& Gaylord, S. A., 2014; Spears et al., 2017). The model's focus on self-as-context may make room for a compassionate and strengths-based approach instead of relying on deficits of the individual, which is reminiscent of pre-existing racist ideas and rules. A strengths-based approach may also allow for a release of guilt and or shame that may be present when internalizing racist conditioning. In addition to mindfulness, the model's heavy use of metaphors may be culturally relevant, given its presence in Black linguistics and cultural expressions (Woodson, 2017). The author does not contend ACT, as it is already formed, will be enough to shape Black liberation, but that its basic tenets with a culturally adapted lens may show utility.

Example of methods to use ACT in the service of Black Liberation:

- Values. As a reminder, values are defined as "rules that function as verbal motivating operations that increase or decrease the effectiveness of stimuli as reinforcers or punishers, thereby supporting overt behaviors that produce those stimuli (Tarbox et al., 2020). This is a crucial component of Acceptance and commitment training/therapy. Values that are self-constructed can be used for Black liberation in a variety of ways. It may serve to ground the individual and center how they interact with themselves and others.

- Examples of Black liberatory values-guiding questions: Consider what about your Blackness is essential. How do you want to show up for your community? How would you live if there were no conditions placed on you related to your Blackness?

- Example Values activity. Blackness in Future: 
- Imagine it is the year 5060. A group of Black youth have just found a time capsule. Inside of it is information about you and the life you lived to help your community. What is inside this box? What story does it tell? What did you give to sow into the lives of these young people?

- Acceptance. Acceptance is active, not passive; it does not mean you need to resign, but rather engage. It refers to a willingness to accept an immediate experience and the emotional reactions that accompany it, and allows for an individual to be present with stimuli without attempting to shift psychological or private events. An example may be someone trying to change feelings of sadness when a racist event occurs by engaging in behaviors such as the active denial of racism. This process of active denial speaks to the process of experiential avoidance and negative reinforcement. Acceptance as a comparison would mean sitting with the emotions, and private verbal behavior that arise, as opposed to denying the activating event. It is with acceptance one may empower themselves to evoke behaviors as a means to shift aversive oppressive contingencies.

Examples of acceptance-guiding tenets: Accept racism exists as opposed to experientially avoiding the emotional reactions that accompany its tangible impacts. Accept learned anti-Black rules and behaviors instead of denying susceptibility to them. Accept resistance to habituating to a racist environment. Accept Black joy as non-contingent reinforcement. Accept Black diversity of thought and patterns of behavior. 
○ Black Suffering Inventory. An example of an acceptance exercise adapted from "Your Suffering Inventory," Steve Hayes(2005):

- Write down a list of all the psychologically difficult issues for you as a result of or in connection to racism. Use the left column to write both external/situational events and your reactions to them. Some may be specific situations you have experienced, and others may not be. An example of a problematic issue that also reflects your response may be "feeling unsafe when I entered an all-white neighborhood." A non-example may be "white neighborhoods." You may include thoughts, feelings, bodily sensations, habits, or urges that distress you. There is no right or wrong answer; just write what you react to. You can include the things you believe bring you pain.

- Once complete, write how long this has been a problem or thought for you.

- Once this is complete, rank the items based on the impact they have in your life (from highest impactful to lowest impactful).

- Lastly, draw arrows between each item on the list that is connected. For example, suppose if one of your items is being told, there is no place for your culture in a specific industry, and the other is being tokenized. If you feel the two are related (i.e., because there is no place for your culture, you can only be a token at work). You may find many connections on your list (or not). 
There is no set amount of links you must draw. It is useful information for yourself, no matter the number of relations formed. If you find items highly ranked on your list and connected to many other things, it may show their importance.

- When you are finished, review your list. This is your racism suffering inventory. It may change over time, but for now, it shows you how you feel racism has impacted/is impacting you.

- Present moment awareness. This process is otherwise known as "mindfulness." It means to maintain attention towards stimuli currently present in the environment. It also means noticing one's own attending behavior (Tarbox et al., 2020).

- Examples of present moment awareness tenets for Black liberation: Noticing and getting curious about how racism impacts your life, on both the smaller and larger scale. Notice body sensations when microaggressions are enacted against you. Noticing when you codeswitch. The desire to shift your wardrobe depending if non-Black people will be present. Noticing when you expect other Black people to conform to the rules regulated by whiteness.

○ Noticing Anti-Blackness. An example of a present moment awareness exercise:

- Read the paragraph below. Actively attempt to place yourself inside this scenario. As you are reading, notice your gut reactions. Notice your bodily sensations. Notice your thoughts. Anytime you 
find yourself attempting to shift or shut down your thoughts, instead of arguing with it, just notice it.

- Imagine you are getting ready for a job interview. You work at a Fortune 500 company in a managerial position. You worked hard to get where you are, and being one of two Black people in your office is a tough role. Inside your office walks a young Black woman for your open corporate, client interfacing position. You orient initially to her face and then notice her hair. It is braided, multicolored with a handful of blue and purple streaks. You glance at her wardrobe. She is dressed in business-appropriate clothing, slacks, a button-up top, and hoop earrings. She takes her seat, and you begin asking her standard interview questions. You segway to a question about efficiency and completing projects timely, "In this position, you may be given many tasks at one time. How do you best manage your time to meet all of your deadlines?" She responds, "nobody got time to waste, so I make a to-do list immediately, ya know? And once I got everything organized, I check everything off as I go along. I didn't always do that, but I quickly learned, you know?" and proceeds to continue her outline of rendering the most efficient outcomes in her work. It is time to decide if this candidate will make it to the next part of the interview. The answer can only be yes or no. You decide 
- Take a moment to sit with this scenario. What came up for you? How did this scenario end? It is important to note that this exercise is not designed to help you change your thoughts or feelings surrounding internalized racism, but rather to notice them and notice your own likely overt behaviors. This kind of flexible, selfdirected attention can then create a context to choose specific overt behaviors that you feel move you toward what you value, perhaps in this case, supporting Black liberation; perhaps, accepting her responses as sufficient and moving towards hiring.

- Defusion. Defusion means observing private behavior, such as thinking, without being governed by it (Moran and Ming, 2020). In other words, defusion deliteralizes or weakens the functional dominance of certain thoughts as discriminative stimuli or rules. This can involve addressing rigid rule-following and resignation to previous stories that an individual was taught. With defusion, one may be able to dispel self-blame and create distance between the rules and one's own behaviors.

Examples of defusion tenets for Black liberation: Consider a rule you have been taught. Maybe, Black people cannot jog in their own neighborhood. Perhaps Black people must present themselves respectably to the world to gain respect from others. Avoid Black women; they have attitudes or are angry? All Black people do is complain. Black people can’t have justice until they fix their own issues. Black people are like crabs in a barrel (pulling each other down as a means to block their success). Black people 
who speak with AAVE are ghetto, unintelligent. Look at the rule, observe it. Now that the rule is in front of you, how may you respond?

- The Freedom Train. An example of a defusion exercise (adapted from Stoddard and Afari, 2014):

- Imagine you are standing in a field of tall grass. Right in front of you is a fence. Beyond the metal barrier, you see train tracks. In the near distance, a train is approaching. This train is a symbolic representation of your mind. As the train starts to pass, you notice writing on the first train car. Each car is a stereotype or rule created about Black people. Imagine what this stereotype/rule is. It could say something like, "Being Black is exhausting," "Black people are uneducated," "Black people have to work twice as hard," "Black people are like second class citizens." Maybe what is written on the cars are stereotypes/rules, ones that evoke emotions from you. Perhaps they are ones that you work tirelessly to prove it false to others. Continue looking at the train. If you begin pulling your attention away from the car, attempting to focus somewhere else, or arguing with the content, stay there for a moment. Notice what thought hooked you. Notice the speed of the train car. It has slowed down. And then, when you are ready, allow the train car to keep moving, picking up speed, and taking notice of the next car. What does this stereotype say? Notice your response to it. Notice 
your desire to act or argue or become hooked. Notice as it too drives past you and disappears into the distance.

- Self-as-Context. Self-as-context refers to flexible self-perspective taking. It allows the individual to analyze their behavior in relation to current environmental stimuli instead of rigidly resorting to previously encountered stimuli or thoughts. For example, someone may say I am Black; therefore, I must work twice as hard (and forgo rest and wellness care). This would reflect being fused to rules. An individual may consider times in which they "deserved" to rest and consider questions like, "is it possible for me to be a powerful advocate for my community and also be a person who takes care of themself? What might that look like?"

- Examples of Self-as-context guiding tenets: Who were you told that you are? Were you taught this through the media? Consider the stereotypes that you have held firm to. Consider the ones you have worked hard to dispel.

- A Heavy Load. An example of a defusion exercise:

- Take a moment to think back to some of the negative messaging you learned about yourself and Black people. If it is helpful, maybe you can write them down. Think of as many as you can. As you think of one/read one message, pretend as if the message is a long sleeve shirt. Put it on. Now think of the next and put on, on top of the last layer. As you are putting on the layers, notice what happens to the shirts. Does it become harder to wear over time? Does it feel heavy? Imagine how it may be to wear these shirts 
around every day. What might wearing this amount of shirts around help you accomplish? What might wearing the shirts prevent you from doing? Now, think about taking off each shirt. Think about how it feels to get rid of each one until you reach your bare skin. A person's self-directed verbal behavior (i.e., thoughts about self) are a result of our conditioning, and they cannot be eliminated, made "correct," controlled, or "taken off," but what we can do is develop flexible and values-directed ways to respond to the many thoughts we have about ourselves, particularly those of internalized racism.

- Committed Action. This is another essential tenet of ACT and speaks to tangible outcomes to be observed as a result of the model. To engage in committed action describes discrete behaviors enacted in connection to their values. For example, someone who may tact Black liberation as a value may enact behaviors such as voting for or advocating for a bill that would grant economic reparations to the Black community.

Examples of committed action guide content: Think back to your value of Black liberation. How can you move towards it? Today?

○ The Committed Action Liberation Plan. An example of a committed action exercise:

If Black Liberation is my value My goal is:

The action(s) I will take to achieve my goal is/are: 
The discomfort(thoughts, emotions, negative consequences I am willing to experience to achieve this goal:

\section{Storytelling/Self-Narration}

"Language as culture is the collective memory bank of a people's experience in history."

Storytelling is an African tradition that extends back further than Black ancestors being sold and stolen from their lands. African people are rooted in oral tradition and folklore. There is kinship and familiarity in the way Black people communicate with one another. Typically, in Africa, storytelling took place in the evening after returning from work (Tuwe, 2016). During that time, children and elders sat around and told their own stories. Children were also asked to retell the elders' accounts as if it were a test to ensure the story was appropriately recalled (Gikandi, 2009).

It is vital to frame the storytelling of African American ancestors because of the core role it played in our oppression and the potential it has to contribute to Black liberation. During slavery, it was illegal to read and write. Verbal behavior, in this case, storytelling, functioned as a way to preserve the experiences of enslaved people in some fashion (Tuwe, 2016). This behavior's function was to transmit information beyond the immediate environment and relay knowledge to forthcoming generations. According to Ngugi wa Thiong'o (1986), language brings about culture. And culture brings, with verbal behavior and written works, values of how we perceive ourselves and our place in the larger world (1986).

Narrative Therapy, sometimes called race narrative therapy (Mbilishaka, 2018), is a treatment modality that addresses private events and verbal behavior emitted in context to social oppression. The central premise rests on the notion that an individual is the expert of their own 
life. A narrative can be a useful tool to promote psychological healing, as it places the ownership of stories back into the hands of the oppressed. Narrative, or ownership of narrative, allows for replacement of previous anti-Black verbal behavior with new verbal behavior dictated by the individual, thus establishing new relations (Taliaferro, 2013). Given the longstanding history of racism, there have been fictitious and harmful stories told about Black people for centuries. Nobles (2013) underscored the importance of remembering the fractured identities of African people as a result of the Maafa (great disaster of enslavement/oppression) and colonization.

Using Narratives and storytelling is a method for Black people to reclaim agency and tell our own stories that may be new or in alignment with elders' stories before colonization. It also allows a space to process the narratives told by others that are fallacies and encourages the externalization of the narrative so that the person can dispel the notion that the stories related to racism are their own (Mbilishaka, 2018). Additionally, it may include the use of archiving their own stories. For Black Americans who have had their history erased, there is power in real-time documentation of events. This allows space for the individual also to narrate their own happiness and joy. Narrative therapy benefits may include increased self-compassion and reduced guilt and shame (Mbilishaka, 2018).

Behavior analysts may incorporate narrative into the ACT modality when considering self as context and defusion processes. The individual may consider the rules they have been taught about themselves and their community. Using defusion may promote Black Liberation by getting untangled from the narrative established by white individuals in history. An example includes the narrative that Black people are prone to committing crimes (The Birth of a Nation, 1915). A Black person who is entangled with this rule that Black people commit crimes, otherwise stated has internalized anti-Blackness, may be likely also to question their safety in a 
Black neighborhood, consider waiting before leaving their vehicle so that a group passes, or has other private events related to the motivation of a group of Black people congregating on a city street. Using narratives not only may allow distance from these thoughts but will enable the individual to reconstruct stereotypes in addition to creating a context to choose different overt behaviors that may help them be more actively supportive of Black liberation.

\section{Trauma-Informed Intervention}

The role of trauma in the Black community is too prominent not to include in this effort. There can be no Black liberation without considering racial trauma. Considering racial trauma should not be an afterthought but a setting event acknowledged in every context. Racial trauma for Black people is conceptualized and approached by community groups and psychologists (Grills et al., 2016; Williams et al., 2018; Anderson and Stevenson, 2019). Behavior analysts can approach Black liberation and relevant intervention with a trauma-sensitive and functional analytic lens (Lincoln et al., 2017; Kolu, 2020). This requires the behavior analyst to consider the history of racial events in context to the behavior of the individual. As previously outlined in this paper, an individual is not required to experience direct contingencies in order to shape their behaviors. Transmitted through verbal behavior, an individual may still experience trauma and therefore evoke behaviors within this context. The assessment or consideration of past trauma, extending 400 years, will allow a behavior analyst to initially withhold contraindicated behavioral procedures (Kolu, 2020) that may harm the individual. A contraindicated procedure for a group of individuals who have undergone physical and emotional abuse would be using error-correction procedures that may be considered aversive to the individual. From behavior analytic literature, individuals who are placed in aversive conditions, such as the presentation of shaming, may select counter-control behaviors (Skinner, 1953). Shame and the evocation of 
counter-control behaviors are not the aims of the model, but rather self-selection of personal values and associated behaviors. This means we cannot shame Black people into liberating themselves from anti-Black racism; however, we can make use of culturally appropriate behavioral processes to aid this outcome.

When preparing intervention, behavior analysts who recognize racial trauma may focus on a transparent consent process, provide clear instructions, and create a safe environment that does not perpetuate past racial abuses. Following an assessment incorporating shared and individual learning history, the behavior analyst can consider targets for programming (i.e., decrease behaviors that impact the individual's own racial liberation) and the methods for behavior change. The behavior analyst can then take data and teach the individual how to take their own data. Lastly, a behavior analyst can program antecedent strategies that would assist the individual in emitting behaviors further in alignment with Black liberation. With the intervention, the behavior analyst should assess current aversive race-based contingencies that may further harm the individual. For example, an individual may determine speaking up against workplace racism (when being terminated is a potential consequence) may not the best behavior to target if the person is also undergoing food or housing insecurity. Recognizing and discriminating competing contingencies that impede an individual from evoking behavior in certain environments is necessary to shield the individual from experiencing further harm. An analyst may then work with the individual to create an intervention that is both in alignment with their value and less self-injurious.

\section{Conclusion}

This paper aims to serve as a starting point for Black Behavior Analysts and non-Black and culturally attuned behavior analysts, to conceptualize Black liberation and consider its place 
in the literature. Black psychological liberation is a socially valid topic, therefore considering a framework such as this one may help the larger world. This framework may also be useful when working with clients who struggle to accept their physical features (skin color, hair, etc.) or generally display rule-governed behavior related to their racial categorization. The use of preestablished frameworks may allow behavior analysts to use existing training to tailor individual interventions. Black liberation will not be actualized through an "unlearning process" but will require specific targeted actions towards that value.

It should also be noted that while this model discusses Blackness in context to social oppression, Blackness is not restricted to this experience. Blackness can exist without and outside of the context of hegemonic whiteness. However, it would be disingenuous not to address a component that has revealed harmful effects to the community; internalized racism and anti-Blackness. Just as the Azibo Nosology outlines the social and political implications of psychological distress, the impacts of private events that have been weaponized by white supremacy should be addressed as well (2015). It is past due for the field of behavior analysis to produce models intentionally designed to center the liberation of historically marginalized groups. I believe Black behavior analysts and non-Black colleagues can use the tools described in this paper, Black psychology, trauma-informed care, ACT, and narrative therapy, to ignite the next phase of evolution in the culture of applied behavior analysis and beyond that lead to positive, measurable outcomes for the Black community. 
Acknowledgements: The author would like to thank her ancestors and community of fierce social justice organizers who have encouraged this manuscript. Thank you for your invaluable contribution to building a better world and liberated community. Additionally, the author would like to thank Jovonnie L. Esquierdo-Leal and each reviewer for their time reading and preparing this manuscript.

Compliance with Ethical Standards: No funding was received to assist with the preparation of this manuscript. The authors have no relevant financial or non-financial interests to disclose.

Ethics Approval: Not applicable as there were no human subjects 


\section{References}

Abrams, J. A., Belgrave, F. Z., Williams, C. D., \& Maxwell, M. L. (2020). African American Adolescent Girls’ Beliefs About Skin Tone and Colorism. Journal of Black Psychology, 46(2-3), 169-194. doi:10.1177/0095798420928194

Alexander, Michelle. (2010). The new Jim Crow : mass incarceration in the age of colorblindness. New York : [Jackson, Tenn.] :New Press ; Distributed by Perseus Distribution.

American Psychological Association. (n.d.). Physiological and Psychological Impact of Racism and Discrimination for African-Americans. Retrieved September 13, 2020, from https://www.apa.org/pi/oema/resources/ethnicity-health/racism-stress

American Psychological Association. (n.d.). Retrieved September 12, 2020, from https://www.apa.org/pi/oema/resources/ethnicity-health/psychologists/sumner-prosser

Anderson, R. E., \& Stevenson, H. C. (2019). RECASTing racial stress and trauma: Theorizing the healing potential of racial socialization in families. American Psychologist, 74(1), 63-75. http://dx.doi.org/10.1037/amp0000392

Awad, G. H., Kashubeck-West, S., Bledman, R. A., Coker, A. D., Stinson, R. D., \& Mintz, L. B. (2020). The Role of Enculturation, Racial Identity, and Body Mass Index in the Prediction of Body Dissatisfaction in African American Women. Journal of Black Psychology, 46(1), 3-28. doi:10.1177/0095798420904273

Azibo, D.A. ya. (2015). Moving Forward with the Legitimation of the Azibo Nosology II. J Afr Am St 19, 298-318. https://doi.org/10.1007/s12111-015-9307-z

Azibo, D. A. ya. (1994). The Kindred Fields of Black Liberation Theology and Liberation Psychology: A Critical Essay on their Conceptual Base and Destiny. Journal of Black 
Psychology, 20(3), 334-356. https://doi.org/10.1177/00957984940203007

Baldwin, J. A. (1979). Theory and Research Concerning the Notion of Black Self-hatred: A Review and Reinterpretation. Journal of Black Psychology, 5(2), 51-77. doi:10.1177/009579847900500201

Baum, W. M. (2017). Understanding behaviorism. Hoboken, NJ: John Wiley \& Sons.

Biglan, A., \& Embry, D. D. (2013). A framework for intentional cultural change. Journal of Contextual Behavioral Science, 2(3-4), 95-104. doi:10.1016/j.jcbs.2013.06.001

Bonilla-Silva, E. (2014). Racism without racists: color-blind racism and the persistence of racial inequality in America. Fourth edition. Lanham: Rowman \& Littlefield Publishers, Inc.

Bor, J., Venkataramani, A. S., Williams, D. R., \& Tsai, A. C. (2018). Police killings and their spillover effects on the mental health of black Americans: A population-based, quasi-experimental study. The Lancet, 392(10144), 302-310.

doi:10.1016/s0140-6736(18)31130-9

Cabral, R. R., \& Smith, T. B. (2011). Racial/ethnic matching of clients and therapists in mental health services: a meta-analytic review of preferences, perceptions, and outcomes. Journal of counseling psychology, 58(4), 537-554. https://doi.org/10.1037/a0025266

Canady, V. A. (2019). APA policy calls spanking harmful discipline for children. Mental Health Weekly, 29(8), 7-7. doi:10.1002/mhw.31790

Chimezie A. Colonized Mentality and Afro-Centric Peoples. Journal of Black Psychology. 1975;2(1):61-70. doi:10.1177/009579847500200108

Clark, A. (2013). Honoring the Ancestors. Journal of Black Studies, 44(4), 376-394. doi:10.1177/0021934713487925

Clark, C. X., Mcgee, D. P., Nobles, W., \& Weems, L. X. (1975). Voodoo or IQ: An Introduction 
to African Psychology. Journal of Black Psychology, 1(2), 9-29.

doi:10.1177/009579847500100202

Comas-Díaz, L., Hall, G. N., \& Neville, H. A. (2019). Racial trauma: Theory, research, and healing: Introduction to the special issue. American Psychologist, 74(1), 1-5. http://dx.doi.org/10.1037/amp0000442

Cooper, J. O., Heron, T. E., \& Heward, W. L. (1987). Applied behavior analysis. Columbus, Ohio: Merrill Pub. Co.

Delgado, R., Stefancic, J., \& Harris, A. (2012). Critical Race Theory: An Introduction, Second Edition. New York; London: NYU Press. Retrieved September 12, 2020, from http://www.jstor.org/stable/j.ctt9qg9h2

Dixon, Mark \& Dymond, Simon \& Rehfeldt, Ruth Anne \& Roche, Bryan \& Zlomke, Kim. (2003). Terrorism and Relational Frame Theory. Behavior and Social Issues. 12. 129. 10.5210/bsi.v12i2.40.

Duttry, Caitlin Rose Riley, "Em(body)ing Autonomy: Black Women’s Bodies and Self-Liberation in the Novels of Zora Neale Hurston and Alice Walker" (2014). Honors Theses and Capstones. 198. https://scholars.unh.edu/honors/198

Festinger, L. (1957). A theory of cognitive dissonance. Stanford University Press.

French, K., Golijani-Moghaddam, N., \& Schröder, T. (2017). What is the evidence for the efficacy of self-help acceptance and commitment therapy? A systematic review and meta-analysis. Journal of Contextual Behavioral Science, 6, 360-374. DOI:

10.1016/j.jcbs.2017.08.002

Gikandi, S. (2009) Fifty Years of Things Fall Apart (1958), Wasafiri, 24:3, 4-7, DOI: $10.1080 / 02690050903019772$ 
Goldiamond, I. (1976). Protection of human subjects and patients: a social contingency analysis of distinctions between research and practice, and its implications. Behaviorism, 4(1), $1-41$.

Graham, Jessica \& Calloway, Amber \& Roemer, Lizabeth. (2015). The Buffering Effects of Emotion Regulation in the Relationship Between Experiences of Racism and Anxiety in a Black American Sample. Cognitive Therapy and Research. 39. 10.1007/s10608-015-9682-8.

Greer, T. M. (2011). Coping Strategies as Moderators of the Relationship Between Race-and Gender-Based Discrimination and Psychological Symptoms for African American Women. Journal of Black Psychology, 37(1), 42-54. https://doi.org/10.1177/0095798410380202

Griffith, D. W., Dixon, T., \& Triangle Film Corporation. (1915). Birth of a nation. Los Angeles, CA: Triangle Film Corp..

Grills, C., Aird, E., \& Rowe, D. (2016). Breathe, Baby, Breathe: Clearing the Way for the Emotional Emancipation of Black People. Cultural Studies Critical Methodologies. 16. $10.1177 / 1532708616634839$.

Hayes, S.C. (2019), Acceptance and commitment therapy: towards a unified model of behavior change. World Psychiatry, 18: 226-227. doi:10.1002/wps.20626

Hayes, S. C., \& Smith, S. (2005). Get out of your mind and into your life: The new Acceptance and Commitment Therapy. Oakland, CA: New Harbinger.

Helms, J. E. (2006). Fairness is not validity or cultural bias in racial-group assessment: A quantitative perspective. American Psychologist, 61(8), 845-859. https://doi.org/10.1037/0003-066X.61.8.845 
Hirschberger, G. (2018). Collective Trauma and the Social Construction of Meaning. Frontiers in Psychology, 9. doi:10.3389/fpsyg.2018.01441

Jamison, D. F. (2018). Key Concepts, Theories, and Issues in African/Black Psychology: A View

From the Bridge. Journal of Black Psychology, 44(8), 722-746. https://doi.org/10.1177/0095798418810596

Jones, H. L., Cross, W. E., \& Defour, D. C. (2007). Race-Related Stress, Racial Identity Attitudes, and Mental Health Among Black Women. Journal of Black Psychology, 33(2), 208-231. doi:10.1177/0095798407299517

Jones, S. C., Lee, D. B., Gaskin, A. L., \& Neblett, E. W. (2013). Emotional Response Profiles to Racial Discrimination. Journal of Black Psychology, 40(4), 334-358. doi:10.1177/0095798413488628

Kolu, C. (2020). Cusp Emergence. Retrieved September 13, 2020, from https://cuspemergence.com/

Lawrence, K., \& Keleher, T. (2004). Structural racism. Retrieved from www.ywcagreaterbaltimore.org/images/structural\%20racism.pdf

Leary-DeGruy, J. (2005). Post traumatic slave syndrome : America's legacy of enduring injury and healing. Milwaukie, Oregon :Uptone Press

Li, A. (2020, August 15). Solidarity: The Role of Non-Black People of Color in Promoting Racial Equity. https://doi.org/10.31234/osf.io/pmqhn

Lincoln, T., Marin, N., \& Jaya, E. (2017). Childhood trauma and psychotic experiences in a general population sample: A prospective study on the mediating role of emotion regulation. European Psychiatry, 42, 111-119. doi:10.1016/j.eurpsy.2016.12.010 
Mattaini, M., \& Holtschneider, C. (2017) Collective Leadership and Circles: Not Invented Here, Journal of Organizational Behavior Management, 37:2, 126-141, DOI: $10.1080 / 01608061.2017 .1309334$

Maxwell, M., Brevard, J., Abrams, J., \& Belgrave, F. (2014). What's Color Got To Do With It? Skin Color, Skin Color Satisfaction, Racial Identity, and Internalized Racism Among African American College Students. Journal of Black Psychology, 41(5), 438-461. doi:10.1177/0095798414542299

Mbilishaka, A. (2018). PsychoHairapy: Using Hair as an Entry Point into Black Women's Spiritual and Mental Health. Meridians. 16. 382. 10.2979/meridians.16.2.19.

Molina, K. M., \& James, D. (2016). Discrimination, internalized racism, and depression: A comparative study of African American and Afro-Caribbean adults in the US. Group processes \& intergroup relations : GPIR, 19(4), 439-461. https://doi.org/10.1177/1368430216641304

Moore, J. C. (2020). We want our bodies back: Poems. New York, NY: Amistad, an imprint of HarperCollins.

Moran, D.J., Ming, S. The Mindful Action Plan: Using the MAP to Apply Acceptance and Commitment Therapy to Productivity and Self-Compassion for Behavior Analysts. Behav Analysis Practice (2020). https://doi.org/10.1007/s40617-020-00441-y

Nobles, W. W. (2013). Fundamental Task and Challenge of Black Psychology. Journal of Black Psychology, 39(3), 292-299. https://doi.org/10.1177/0095798413478072

Osgood, C. E., \& Tannenbaum, P. H. (n.d.). The principle of congruity in the prediction of attitude change. Indianapolis: Bobbs-Merrill.

Pieterse, A. L., Todd, N. R., Neville, H. A., \& Carter, R. T. (2012). Perceived racism and 
mental health among Black American adults: A meta-analytic review. Journal of Counseling Psychology, 59(1), 1-9. doi:10.1037/a0026208

Ramone, J. (2014). Towards collective liberation. Ephemera: Theory \& Politics in Organization, 14(4), 1049-1055.

Skinner, B. F. (1953). Science and human behavior. Macmillan.

Smith, W. D. (1974). Editorial. Journal of Black Psychology, 1(1), 5-6. doi:10.1177/009579847400100101

Solano-Flores, G. and Nelson-Barber, S. (2001), On the cultural validity of science assessments. J. Res. Sci. Teach., 38: 553-573. doi:10.1002/tea.1018

Solly, M. (n.d.). 158 Resources for Understanding Systemic Racism in America. Retrieved September 12, 2020, from https://www.smithsonianmag.com/history/158-resourcesunderstanding-systemic-racism-america-180975029/

Spears, C. A., Houchins, S. C., Bamatter, W. P., Barrueco, S., Hoover, D. S., \& Perskaudas, R. (2017). Perceptions of Mindfulness in a Low-Income, Primarily African American Treatment-Seeking Sample. Mindfulness, 8(6), 1532-1543. doi:10.1007/s12671-017$0720-3$

Stoddard, J. A., \& Afari, N. (2014). The Big Book of ACT Metaphors: A Practitioner's Guide to Experiential Exercises and Metaphors in Acceptance and Commitment Therapy. Oakland, CA: New Harbinger Publications

Taliaferro, J. D., Casstevens, W. J., \& Gunby, J. T. D. (2013). Working with african american clients using narrative therapy: An operational citizenship and critical race theory framework. The International Journal of Narrative Therapy and Community Work, (1), 34-45. Retrieved from 
https://search.proquest.com/docview/1495405324?accountid=166077

Tarbox, J., Szabo, T. G., \& Aclan, M. (2020). Acceptance and Commitment Training Within the Scope of Practice of Applied Behavior Analysis. Behavior Analysis in Practice. doi:10.1007/s40617-020-00466-3

Taylor, K. (2017). How we get free - black feminism and the combahee river collective. Haymarket Books.

Thiong'o, N. (1986). Decolonising the mind : the politics of language in African literature. London : Portsmouth, N.H. :J. Currey ; Heinemann.

Truong, K. A., \& Museus, S. D. (2012). Responding to racism and racial trauma in doctoral study: An inventory for coping and mediating relationships. Harvard Educational Review, 82(2), 226-254. https://doi.org/10.17763/haer.82.2.u54154j787323302

Turner S.M. (1982) Behavior Modification and Black Populations. In: Turner S.M., Jones R.T. (eds) Behavior Modification in Black Populations. Springer, Boston, MA. https://doi.org/10.1007/978-1-4684-4100-0_1

Tuwe, K. (2016). The African Oral Tradition Paradigm of Storytelling as a Methodological Framework: Employment Experiences for African communities in New Zealand. Retrieved September 13, 2020, from https://www.ecald.com/resources/publications/?filter=true

Utsey, S. O., Giesbrecht, N., Hook, J., \& Stanard, P. M. (2008). Cultural, sociofamilial, and psychological resources that inhibit psychological distress in African Americans exposed to stressful life events and race-related stress. Journal of Counseling Psychology, 55(1), 49-62. https://doi.org/10.1037/0022-0167.55.1.49

Utsey, S. O. (1999). Development and validation of a short form of the Index of Race-Related 
Stress (IRRS)-Brief Version. Measurement and Evaluation in Counseling and Development, 32(3), 149-167.

Wilkins, E. J., Whiting, J. B., Watson, M. F., Russon, J. M., \& Moncrief, A. M. (2012).

Residual Effects of Slavery: What Clinicians Need to Know. Contemporary Family Therapy, 35(1), 14-28. doi:10.1007/s10591-012-9219-1

Williams, M., Printz, P.D., \& DeLapp, R. (2018). Assessing Racial Trauma With the Trauma Symptoms of Discrimination Scale. Psychology of Violence. 8. 735-747. 10.1037/vio0000212.

Woods-Giscombé, C. L., \& Gaylord, S. A. (2014). The Cultural Relevance of Mindfulness Meditation as a Health Intervention for African Americans. Journal of Holistic Nursing, 32(3), 147-160. doi:10.1177/0898010113519010

Woodson, A. (2017) 'Being black is like being a soldier in Iraq': metaphorical expressions of Blackness in an urban community, International Journal of Qualitative Studies in Education, 30:2, 161-174, DOI: 10.1080/09518398.2016.1243269

Wolf, M. M. (1978). Social validity: The case for subjective measurement or how applied behavior analysis is finding its heart1. Journal of Applied Behavior Analysis, 11(2), 203-214. doi:10.1901/jaba.1978.11-203 